\title{
Establishing research universities in Ukrainian higher education: the incomplete journey of a structural reform
}

\section{Myroslava Hladchenko, Harry F. de Boer \& Don F. Westerheijden}

To cite this article: Myroslava Hladchenko, Harry F. de Boer \& Don F. Westerheijden (2016) Establishing research universities in Ukrainian higher education: the incomplete journey of a structural reform, Journal of Higher Education Policy and Management, 38:2, 111-125, DOI: 10.1080/1360080X.2016.1150232

To link to this article: $\mathrm{http}: / / d x . d o i . o r g / 10.1080 / 1360080 X .2016 .1150232$

Published online: 26 Feb 2016.

Submit your article to this journal $\llbracket$

III Article views: 22

View related articles ־

View Crossmark data $\asymp$ 


\title{
Establishing research universities in Ukrainian higher education: the incomplete journey of a structural reform
}

\author{
Myroslava Hladchenko ${ }^{\mathrm{a}, \mathrm{b}}$, Harry F. de Boer ${ }^{\mathrm{a}}$ and Don F. Westerheijden ${ }^{\mathrm{a}}$
}

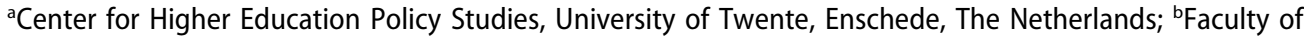
Humanities and Pedagogy, National University of Life and Environmental Sciences of Ukraine, Kyiv, Ukraine

\begin{abstract}
The idea of the research university as a key institution for social and economic development in knowledge-intensive societies has been adopted by the Ukrainian government after the fall of the communist regime. Establishing research universities is a long journey during which many things might happen. To understand this journey better in the case of Ukrainian research universities, we applied an analytical framework derived from the concept of travel and translation of ideas. This concept analyses reform through three types of editing rules: the rules of context, logic and formulation. These editing rules have guided our analysis of data gathered from policy documents complemented by face-toface interviews. We conclude that the idea as introduced came to little, as the turbulent political context precluded long-term planning and universities were faced with conflicting policies.
\end{abstract}

\section{KEYWORDS}

Editing rules; research universities; structural reform; translation of ideas; Ukrainian higher education

\section{Introduction}

When Ukraine gained independence in 1991, the higher education system needed to be reformed to become a well-respected part of the global and European higher education. Reforms require initiative by national policy makers, the legislature or the government. This especially holds true for Ukraine where the national government has considerable authority over the higher education system, through stringent regulation and funding. In this article we explore a structural reform in Ukrainian higher education and why it has not led to the transformation that was desired, namely, the intention of the government to establish research universities in the Ukrainian higher education landscape.

One of the mainstays in contemporary society is that it needs places in which to concentrate the best minds of society in order (1) to maintain knowledge and pass it on to the next generations and to the rest of society, and (2) to develop new knowledge on a global scale and/or in the specific context of place, time and circumstances of this society. The connection between acquiring new knowledge (research) and disseminating it (education and knowledge transfer) is widely advocated. In broad terms, this connection is the rationale of the research university. Research universities are 
institutions committed to research in 'all' their activities, fostering a research culture from teaching and learning to their engagement with business, government and other broader community (AAU, LERU, G8 and C9, 2013).

We focus on Ukraine for two reasons. First, this country and its higher education reforms have received little attention in the academic literature. Second, this case study provides an opportunity to explore how a global idea comes to be translated into national policy.

Establishing research universities is a 'long journey', starting with the introduction of an idea and ending with the real transformation of (some) universities. During this journey, many things might happen that can lead to an adapted version of the original idea or that can prevent a successful implementation of such structural reform. Therefore, the twofold research question for this article is: (1) how did the idea to establish research universities enter Ukrainian higher education and (2) how was this idea translated into the local context(s)?

\section{The normative model of the research university idea}

The prime mission of the research university is to generate research and produce graduate students. The research university is a key institution for social and economic development in a knowledge-intensive society (Mohrman, Ma, \& Baker, 2008). Countries benefit from having 'academic institutions that are linked to the global academic system of science and scholarship so that they can understand advanced scientific developments and participate selectively in them' (Altbach, 2009, p. 16). Research universities are central to a country's capacity for both research and advanced education (Kearney \& Lincoln, 2013). They provide the key link between global science and scholarship and a country's scientific and knowledge system (Altbach, 2013).

To achieve their mission, research universities must be provided with the necessary infrastructure and intellectual environment (Altbach, 2013; Mohrman et al., 2008), such as libraries with access to international databases, well-equipped laboratories, technicians, and administrative support. Universities that wish to be considered researchoriented need to participate in international scientific and other scholarly networks and collaborate and compete with institutions worldwide. For example, they should provide funding for staff to attend conferences.

In Europe the idea of the research university is an inseparable part of the knowledgebased economy. In 1997, the European Union adopted the goal of becoming the most competitive and dynamic knowledge-based society in the world because it saw knowledge production and diffusion as the engine of economic and social progress (Commission of the European Communities [COM], 1997). 'Given that they are situated at the crossroads of research, education and innovation, universities in many respects hold the key to the knowledge economy and society' (COM, 2003, p. 5).

The idea of the research university is connected with another global idea - that of the world-class university. Altbach (2004) agrees on a definition of a world-class as ranking among the foremost in the world and being of an international standard of excellence. Altbach (2004) and Salmi (2009) noted the following characteristics of a world-class university: excellence in research; academic freedom and an intellectually stimulating 
environment; internal self-governance by academics over key aspects of academic life; and adequate facilities and funding. The characteristics of a research university and a world-class university coincide, because a world-class university must operate in the global context, competing with the best academic institutions in the world (Altbach, 2004), but not every research university can become a world-class university.

\section{Travelling and translation of ideas}

According to Beland and Cox (2010, p. 3), 'Across the social sciences, ideas are increasingly recognised as major factors in politics'. Ideas are a primary source of political behaviour (Beland \& Cox, 2010) and it is commonly accepted that ideas from one political setting are used in the development of policies, administrative arrangements, institutions and ideas in another political setting (Dolowitz \& Marsh, 2000). Dolowitz and Marsh (2000) developed a conceptual framework that explains the relationship between policy transfer and policy success and failure (uninformed, incomplete and inappropriate transfer).

Ideas travel in time and space across countries, become materialised and are finally manifested in organisational and human behaviour. The metaphor of travel is used to describe the circulation of ideas to emphasise that they do not flow automatically, but typically they follow certain highly structured and well-worn routes (Czarniawska \& Sevón, 1996). The travel metaphor is helpful in the sense that it directs our attention to travel routes and means of travel. Connections between actors in the field may explain the likely routes through which ideas travel (Rogers, 1983).

Ideas do not diffuse spontaneously in a vacuum but are actively transferred and translated in a historically grown context of other ideas, actors, traditions and institutions. A certain degree of path dependency is therefore inevitable, though from an epistemology rooted in methodological individualism, individual agents and social networks are key to this process of translation (Czarniawska \& Joerges, 1996). Agents who transport ideas play a significant role through their perception of the ideas and contexts. It is therefore important to explore who transports and supports certain ideas as well as how they are packaged, formulated and timed (Czarniawska \& Joerges, 1996).

According to Degn (2014, p. 32), 'Such processes, where ideas tend to move over time and space, are best described by the concept of translation, indicating a dynamic approach to the process of travel'. Translation is the process whereby a general policy idea is transferred and reinterpreted in a new setting (Czarniawska \& Sevón, 1996; Sahlin-Andersson \& Engwall, 2002).

This translation of ideas can be analysed as an editing process. Editing rules guide the process of translation. As regards the rules of editing of translation processes Sahlin and Wedlin (2008; see also Sahlin-Andersson, 1996) distinguish:

- Rules of context which help to recontextualise an idea, disconnecting it from the previous, local setting and making it appropriate for the new one.

- Editing entails use of a plot or rules of logic that explain causes and effects of the translation, 'allowing prototypes to follow a problem-solving logic and an application process or implementation plan, to be explained in relation to the actions of 
certain actors' (Morris \& Lancaster, 2006, p. 213). Thus, editing follows a path from broad context leading to a specific logic of action. Brunsson (1989) clearly distinguishes talk - decision - action in problem-solving logic. In this article we are interested in the talk, and that may not be directly connected with actual problem-solving, though probably the rules of the game of policy require that the talk be couched in terms of problem-solving: a policy should be presented as good to improve the national situation, in order for the policy to gain legitimacy in the eyes of salient stakeholders.

- Rules of formulation or relabelling of an idea in an appropriate way so that it seems changed but recognisable at the same time (Morris \& Lancaster, 2006).

In order to explore the travel and translation of the idea of the research university into Ukrainian higher education, we will use these three sets of editing rules - the rules of context, the rules of logic and the rules of formulation.

\section{Research method and methodological considerations}

In Brunsson's terms, our study is about 'talk': we are interested in the discourse on the intention to establish the 'research university' in Ukraine (Brunsson, 1989). Vehicles for 'talk' or discourse, or channels of communication, include written pieces on policy, influencing popular opinion, and academic debate (i.e., three areas of written sources), and verbal discussion/debate. The former are analysed through documentary analysis (policy documents - official transcripts of parliamentary debates, white papers written by the government - and university documents, e.g., statute), the latter through interviews.

The period covered by this study was 2007-2014, with 2007 being the first time the idea of the research university appeared in official Ukrainian documents. The number of documents reporting on the concept of the research university however is rather limited. Therefore, interviews were required to fully explore the travel of this idea. The aim of the interviews was to discover additional information not covered in the documents and give the opportunity to evaluate the validity of the respondents' answers by observing non-verbal behaviour, which is particularly useful when exploring sensitive issues. In addition, face-to-face contact can motivate participation from respondents who would otherwise not bother to complete a questionnaire (Gordon, 1975).

Academics and representatives of the Ministry of Education and Science of Ukraine, for example, the minister and deputy ministers, heads of the departments in the Ministry of Education and Science of Ukraine in the period 2007-2014 $(N=12)$ who participated in the preparation of the documents about establishment of research universities were interviewed about causes and effects of the establishment of the research universities, about formulation (relabelling) and re-contextualisation of the idea of the research university. The interviews were conducted between October 2014 and March 2015 and were designed as semi-structured protocols and conducted face to face with sufficient room to digress from the interview-guide and pursue subjects and themes that the respondents deemed meaningful. 


\section{Analysis - structural reform in Ukrainian higher education: travel and translation of the idea of the research university}

\section{The rules of context: Soviet heritage and tendencies of the higher education in independent Ukraine}

The transition from central planning to a free market economy in post-communist countries in Central and Eastern Europe was uneven. In the early days of the transition processes, two schools of thought on economic reforms emerged. Some economists argued for a rapid break with the past ('shock therapy'), whilst others opted for an incremental approach ('gradualism'). The more westernised countries in Central and Eastern Europe such as Estonia, Latvia, Lithuania, Poland, Hungary, the Czech Republic, Slovakia, Slovenia and Croatia chose rapid economic transition, joined the European Union and are outperforming those former Soviet bloc countries that took a gradual approach (e.g., Belarus, Bulgaria, Albania, Romania, Kazakhstan, Turkmenistan, Armenia, Ukraine). The different reform strategies explain readily the difference in outcomes and the increasing gap between the two groups of transition countries (Lenger, 2008).

Concerning countries that had a common Soviet Union legacy, for example, the Baltic States (Estonia, Latvia and Lithuania) have made significant efforts to break away from the previous Soviet structure of higher education and science. The Baltic States now have binary higher education systems, which distinguish between researchoriented higher education and higher professional education. In 1992, the Latvian Academy of Sciences was reorganised into a classical (personal) type of Academy, socalled 'club of gentlemen/women' and former Latvian Academy of Sciences research institutes were integrated into universities (Parliament of the Republic of Latvia, 1995). The same happened in Estonia and Lithuania (Parliament of the Republic of Estonia (Riigikogu), 1992; Parliament of the Republic of Lithuania, 2009).

Other post-Soviet countries such as Russia, Belarus, Kazakhstan and Ukraine maintained a unitary system of higher education in which the distinction between university education and higher professional education is often not clear. The Ukrainian system of higher education inherited features from the Soviet model, such as the division between higher education institutions which were primarily teaching-oriented (Parliament of Ukraine, 2002) and the research institutes of the Academy of Sciences, which persisted after 1991 without teaching obligations. In 1984, in Ukraine there were 146 higher education institutions but among them only nine comprehensive universities. All the others were mono-disciplinary pedagogical, agricultural, medical, art and culture or technical higher education institutes (Bunina, 2013).

The tendency in those other post-Soviet countries to re-badge higher education institutions whatever their character as universities took place in Ukraine after 1991. This has been called 'universitisation' (But'ko, 2013; Maximova-Mentzoni, 2013). From one point of view, changes in the social-economic way of living in the countries forced higher education institutions to modify former narrow educational programs and develop a fundamental educational approach. Another popular view of explaining 'universitisation' emphasised 'prestige' and 'state funding' (But'ko, 2013; MaximovaMentzoni, 2013). The 'new' universities probably missed a whole set of university education features (Maximova-Mentzoni, 2013). Their transformation in most cases 
concerned launching popular humanities and business specialisations which changed specialised single-discipline higher education institutions into multiple-discipline ones - in that sense becoming similar to comprehensive universities (Borisov \& Zapryagaev, 2001).

Until 1991, all higher education institutions in Ukraine were state-owned and fully dependent on state authorities. In 1991, the adoption of the Law on Entrepreneurship (Parliament of Ukraine, 1991a), which allowed the establishment of private higher education institutions, contributed to the emergence of a market for higher education services. Later public higher education institutions were permitted to charge up to 49 per cent of admitted students a tuition fee (Parliament of Ukraine, 2002). These changes led to the emergence of competition among higher education institutions for students and resources, and to massification of higher education. Since 1990/1991, there has been a gradual increase in the number of public higher education institutions, and a private sector of higher education emerged. In 2008/2009, 353 higher education institutions were authorised to provide next to bachelor's also master's, doctoral and postdoctoral courses. In the following years, there was a slight decrease from this peak number (State Statistics Service of Ukraine, 2015).

Besides massification and universitisation of higher education, in 1994 another change occurred in the landscape of Ukrainian higher education - the first two flagship universities received the status of 'national university'. Expanding this event into an idea, higher education institutions that were nationally and internationally recognised could be given the status of 'national' (President of Ukraine, 1995, 1996). At the time, it was forecast to establish 51 national universities in 17 disciplines. The Ukrainian presidents were 'generous' in awarding the status of national university especially before elections. As a result, the system grew to 117 national universities (Stadnyi, 2013), more than double the number initially expected.

The original idea was that the national universities would enjoy the privilege of additional funding (Oleksiyenko, 2014) but because of constant economic crises in the country, there were problems with allocation of funding. Stadnyi (2013) states that the idea of the national university failed due to economic problems and to the absence of an adequate system of evaluation of higher education institutions. The establishment of research universities was in some way a logical continuation of the earlier efforts at structural change through universitisation and the creation of national universities.

A consequence of the constant crises in national economy was that Ukraine dropped from 51st to 56th on the Knowledge Economy Index (KEI) between 2008 and 2012 (World Bank, 2008, 2012), emphasising that Ukraine was not succeeding in transforming itself into a knowledge society. The Knowledge Economy Index shows whether the environment is conducive to the effective use of knowledge in economic development; in Ukraine, all governments were oriented more on borrowing from the International Monetary Fund than on developing a knowledge-based economy.

\section{Rules of logic: the Ukrainian plot}

Rules of logic aim to clarify causes and effects and to present a problem-solving logic to adoption of a new idea in policy. The idea of the research university was brought into the political discourse by actors from academia. In the period 2004-2006, the National 
Technical University of Ukraine 'Kyiv Polytechnic Institute' (hereafter shown as Kyiv Polytechnic Institute) participated in a TEMPUS project entitled 'Bridging the gap between university and business', in which European higher education institutions, such as Delft University of Technology (the Netherlands), the Royal Institute of Technology (Sweden) and the Polytechnic University of Catalonia (Spain) were also involved. As a consequence of participation in this project the Science Park 'Kyivska Polytechnika' was established in 2006.

Connected with this TEMPUS project, the rector of Kyiv Polytechnic Institute started a major discussion in the Ukrainian press on the knowledge economy in Europe and on the central role of research universities in building the knowledge economy. He asserted that in Ukraine, taking as an example a Europe of knowledge, higher education institutions must be the basis for the development of the knowledge economy in the country (Zgurovskyi, 2005, 2006). Analysing the European experience, he voiced the necessity to establish research universities in Ukraine in order to build a knowledge-based economy (Zgurovskyi, 2006). In more detail he said in his interview with us:

The research university is necessary for the country in order to build a knowledge-based economy. The main idea of the research university is the triangle of knowledge - education, science and innovation; the university must be the core of the innovation. It's up to the state to provide scientists with a high enough salary in order for them to have all conditions just to focus on research and to create a legislative basis beneficial for knowledge transfer. And it's up to universities and business to develop productive relationships through knowledge transfer.

This rector had also been head of the Public Board of the Ministry of Education and Science of Ukraine (an advisory board of the Ministry). He presented this idea to the education ministry and as a result a new policy was adopted, the 'State Targeted Scientific-Technical and Social Program "Science in Universities" for 2008-2012', declaring the intention of the government to establish five research universities (Cabinet of Ministers of Ukraine, 2007a). A respondent from the education ministry confirmed: 'The aim was to provide the flagship Ukrainian universities with an impulse to develop research and innovation and to support them.' The program declares as its goal 'stimulating research in universities and strengthening the nexus between research and education in order to educate a new generation of highly-skilled professionals for scientific sectors of the national economy and performing competitive research and development activities, implementation of innovation activity in market conditions, taking into consideration the goals and objectives of the development of the national innovation system' (Cabinet of Ministers of Ukraine, 2007a). The program also aimed to increase the collaboration of research institutes of the National Academy of Sciences of Ukraine and sectoral academies of sciences with universities by establishing science and education centres. The government planned to allocate to research universities additional funding for research and modernisation of research infrastructure, but it expected universities to earn through research an amount equal to half of the state funding for research (Cabinet of Ministers of Ukraine, 2007a). In addition, the state expected that the implementation of the Program would contribute to Ukraine's joining the European research and education area. 
The Program was approved in September 2007 by the Cabinet of Ministers of Ukraine headed by the Prime Minister, Victor Yanukovych, and in November 2007, the Cabinet of Ministers of Ukraine approved the 'Statute of National Technical University of Ukraine 'Kyiv Polytechnic Institute' (Cabinet of Ministers of Ukraine, 2007b). In this statute of November 2007 the Kyiv Polytechnic Institute declared itself 'an autonomous public higher education institution of research type' (Cabinet of Ministers of Ukraine, 2007b), thus using a designation that can be seen as a translation of 'research university' for the first time.

A few months later, a new Cabinet of Ministers of Ukraine was appointed under the new Prime Minister, Yulia Tymoshenko. In 2008 all that was done in order to establish research universities was issuing the decree 'On Raising the Status of Taras Shevchenko National University of Kyiv' (President of Ukraine, 2008). As one interviewee explained:

The state wanted to provide Taras Shevchenko National University of Kyiv with stimulus and support, including finance for becoming a world-class research university. It was expected the university to enter into world rankings and to present Ukraine on the international level.

Taras Shevchenko National University of Kyiv was promised benefits from the state such as a salary increase for its academic staff and additional funding for international study visits by staff and students and increased state funding for research (President of Ukraine, 2008).

From the Program, in which the intention of the government to establish research universities was declared, the idea spread among university rectors, who regarded it as an opportunity to increase their status and to obtain additional funding (translating this into a new opportunity for them, very much like being awarded the status of national university). Presidential elections were scheduled for autumn 2009 (eventually held early 2010) and already in July 2009, the Cabinet of Ministers awarded the status of research university to six universities and some months later to a seventh one. In addition, in 2009 at the 'widening meeting' of the Cabinet of Ministers headed by Yulia Tymoshenko, in which rectors of the leading Ukrainian higher education institutions participated, quantitative criteria for research universities were announced. Among the privileges promised to newly established research universities, the government planned to award them additional funding starting in 2011 expecting that the crisis in the national economy would be over by that time (Ukrainian Independent Information Agency of News [UNIAN], 2009).

In January and February 2010, two rounds of presidential elections were held. Four days before the second round, Yulia Tymoshenko, the Prime Minister and the presidential candidate, awarded the status of research university to another six universities. The Cabinet of Ministers promised benefits to research universities such as doubling the salaries of the academic staff for 2011-2012, additional funding for international study visits by staff and students and additional state funding for research infrastructure (Cabinet of Ministers of Ukraine, 2009a, 2009b, 2009c, 2009d, 2009e, 2010a).

Ten days after the second round of the presidential election a further twist occurred in the government's 'translation' of the idea of the research university: the Cabinet, still headed by Yulia Tymoshenko, as she did not win the presidential election, adopted 28 quantitative criteria for research universities focusing on research production. Research 
universities were obliged to prove their research university status within 5 years according to these 28 indicators (Cabinet of Ministers of Ukraine, 2010b). During the first 5 years, research at those universities would be financed from the state budget, and the share of this funding in the state budget of the university would comprise not less than 25 per cent. This meant a significant increase in the state funding for research universities because in other universities this share was usually about 10 per cent (Parliament of Ukraine, 1991b). In addition, it was stipulated that research universities would receive state funding after these 5 years only if their external research earnings equalled half the state funding for research.

Then in another twist, the newly elected president Yanukovych (the one who was forced from office by the Revolution of Dignity in 2014) appointed a new Prime Minister. The new Cabinet of Ministers awarded the status of research university to one more university, introduced three new criteria for research universities and changed some of the previous criteria. Moreover, the status of research university had to be proven, and significant income from private parties must be earned, already in the beginning of 2011, not after 5 years (Cabinet of Ministers of Ukraine, 2010c).

As these almost chaotic policy developments (in Table 1) show, the actors involved in introducing research universities into Ukraine engaged in different problem-solving logic. Politicians who awarded the status of research university wanted to get universities' support at elections by promising them abundant funding and expected them to start earning externally large amounts in 5 years' time. The government which came to the power after elections was obliged to implement the promises of their predecessors but they 'translated' it into their own interpretation of the research university by adding new criteria and requiring the research universities to prove their status and earn significant income from private parties almost immediately instead of in 5 years. In response to these highly fluctuating policies, some academics tried to resolve the problem of the gap between universities and business; other academics tried to obtain more funds for their ailing universities.

Table 1. Chronology of events.

\begin{tabular}{|c|c|}
\hline Date & Event \\
\hline $2004-2006$ & $\begin{array}{l}\text { Kyiv Polytechnic Institute participates in TEMPUS project 'Bridging the gap between university } \\
\text { and business' and the first science park 'Kyivska Polytechnika' is established. }\end{array}$ \\
\hline September 2007 & $\begin{array}{l}\text { Cabinet of Ministers approves the 'State Targeted Scientific-Technical and Social Program } \\
\text { "Science in Universities" for 2008-2012' in which declares an intention to establish five research } \\
\text { universities. }\end{array}$ \\
\hline November 2007 & $\begin{array}{l}\text { Cabinet of Ministers approves the statute of Kyiv Polytechnic Institute in which university } \\
\text { declares itself 'an autonomous public higher education institution of research type'. }\end{array}$ \\
\hline 2008 & $\begin{array}{l}\text { Decree 'On Raising the Status of Taras Shevchenko National University of Kyiv' about measures } \\
\text { aimed to transform this university into research one. }\end{array}$ \\
\hline July 2009 & Six universities are awarded the status of research university. \\
\hline September 2009 & One more university is awarded the status of research. \\
\hline January 2010 & First round of presidential elections. \\
\hline 3 February 2010 & Six more universities are awarded the status of research university. \\
\hline 7 February 2010 & Second round of presidential elections, lost by Prime Minister Tymoshenko \\
\hline 17 February 2010 & $\begin{array}{l}\text { Resolution 'On Approval of the Regulations on Research University' which contains } 28 \text { criteria } \\
\text { and universities are required to prove their status in } 5 \text { years. }\end{array}$ \\
\hline March 2010 & President Yanukovych appoints new Cabinet of Ministers \\
\hline March 2010 & One more university is awarded the status of research one \\
\hline August 2010 & $\begin{array}{l}\text { Cabinet of Ministers adds three new criteria of research university, makes some changes in } \\
\text { previous criteria and requires universities to prove their status in the beginning of } 2011 .\end{array}$ \\
\hline
\end{tabular}




\section{Relabelling: the rules of formulation}

The primary mission of the research universities was formulated to be 'to educate highly-skilled professionals and to conduct competitive research and development activities' (Cabinet of Ministers of Ukraine, 2007a, 2007c). In 2008, in connection with Taras Shevchenko National University of Kyiv, the idea of the research university was formulated as establishment of a world-class university. Only in 2010, at the time of defining the quantitative criteria (and after the statuses of research university were awarded) did an official definition of a research university appear: 'a national higher education institution which has significant achievements, does research and innovation, ensures the nexus between education, science and industry, and takes part in international projects' (Cabinet of Ministers of Ukraine, 2010b). This textual definition was operationalised into the 28 quantitative criteria mentioned before. Prime among these research production oriented performance indicators were, for instance, defence of 300 candidate of sciences (equivalent of $\mathrm{PhD}$ ) and 50 doctor of sciences theses in 5 years; publication of 200 monographs and textbooks; employment of 150 full-time academics with doctor of sciences degree and 500 with candidate of sciences degree; functioning of 15 scientific boards at which candidate of sciences and doctor of sciences theses can be defended; a library with one million books; at least 50 foreign students in the master and doctoral programs; publishing at least 150 articles in journals indexed in international databases (Web of Science, Scopus) per year; and national and international study visits of 50 young academics and students per year (Cabinet of Ministers of Ukraine, 2010b). The status of research university was awarded by the Cabinet of Ministers but it was up to the education ministry to develop the criteria for the research universities. The paradoxical relabelling was that the ministry took its inspiration for quantitative criteria from the familiar Russian research universities' context. The quantitative criteria, therefore, were not based on the idea of research universities in Western Europe, where the travel of the research university had initially started. Moreover, the quantitative criteria had little in common with the expectation of the government that research universities would earn a substantial proportion of their research funding externally. The expectation that universities would earn externally was directly connected with the establishment of a knowledge-based economy - though with stress on knowledge transfer and on monetary benefits (next to public funding), rather than on the idea of the research university as the core institution for knowledge discovery.

Notwithstanding the introduction of research universities, in Ukraine there still were the National Academy of Sciences of Ukraine and sectoral academies of sciences, which received the largest part of the state funding for research. The funding of the National Academy of Sciences of Ukraine and sectoral academies of sciences annually was 3.5 higher than the total budget for education of the two flagship Ukrainian universities together, that is, Kyiv Polytechnic Institute and Taras Shevchenko National University of Kyiv (Kovalchuk, 2010). The situation contrasts with the situation in, for example, the Baltic States, where the research institutes had been made to merge with universities to boost universities' research capacity. Such a reform was not on the agenda in Ukraine.

The idea of the research university was formulated in different ways when it was being translated by different actors: the initial idea about the research university as a part of knowledge-based economy was first transformed into the concept of the world- 
class university, and then transformed again by quantitative criteria which had little in common with the expectation that the universities would earn significant external funding in 5 years. In 2010, the new Cabinet changed the criteria of research universities including demanding universities already in the first year to earn significant income externally (knowing that it was impossible under Ukrainian conditions) in such a way justifying why it did not have to allocate the funding promised by Tymoshenko's Cabinet. Equally far beyond practicability was a new criterion requiring immediate establishment of a science park at each research university. Each agent in the process added its vision in the formulation of the idea of the research university. Moreover, during the period between 2007 and 2010 while the idea was being formulated into policy, the politicians in the education ministry and the government changed, leading to a further loss of consistency and renewed relabelling.

As a result of this repeated process of reformulation there was a disparity between knowledge/research, earning money, and the quantitative criteria.

\section{Conclusions}

We explored the translation of the idea of the research university applying the theoretical framework of the rules of editing. Concerning the first set of these rules, about context, the global idea of the research university travelled from the European context of technological universities (remember the TEMPUS project with Delft University of Technology, the Royal Institute of Technology, and the Polytechnic University of Catalonia), and it landed in a post-Soviet Ukrainian reality, in an economy which was far from being a knowledge economy and which staggered on for years by relying on a constant stream of foreign borrowings, in a country in constant financial crisis, in a country with a higher education system where the term 'university' did not correspond to the meaning it has in European realities and where a significant portion of research funding was allocated to the National Academy of Sciences of Ukraine and sectoral academies of sciences.

Different agents had different perceptions of the logic of translation as they aimed to resolve different problems. Academics brought the idea of the research university into the political discourse to gain attention from Ukrainian politicians for the problems of the development of science in Ukraine. The initiators of the translation of the idea linked it with the establishment of Ukraine's first science park; they were serious about research universities doing research even if the focus was more on innovation-oriented research rather than on curiosity-driven, fundamental research. However, that fits in with their context of technological universities. In 2008, the state was interested in establishing a world-class university, which was regarded to be the same as a research university. Later, in 2009 , the idea of the research university was used by the government in order to gain support in elections.

Looking at the rules of formulation it can be stated that because of the lack of systemic vision on development of the knowledge economy in the country, and a lack of the funding, the idea of the research university was hollowed-out while travelling into the Ukrainian discourse. The state did not create conditions suitable for knowledge transfer between universities and business, and universities had funding for neither equipment for laboratories, nor working conditions that would 
enable academics to engage in research (salary, conference allowances, etc.). In the normative model of a research university, abundant funding is a necessary condition. From one point of view, Ukrainian government used the idea of the 'research' university as an opportunity to receive loyalty of higher education institutions in elections held in 2010. From another point of view, the government expected beneficial results from universities in knowledge transfer and third party funding. This second view, too, is a peculiar translation of the idea of the research university, driven rather by current fiscal and economic stringencies than by long-term visions of actually building a knowledge economy.

Our exploration has shown the importance of the agents who translate the global idea into national policy and how each of them translated it in a different way. In general, success or failure of reform depends on the interpretation of the idea by these actors in the process of translation, on the context from which they translate and into which they translate, how they see the causes and effects of translation, what problems they aim to resolve and how they formulate new policy. In summary, the establishment of research universities in Ukraine really is an incomplete journey because of an uninformed, incomplete and inappropriate transfer of the idea of the research university (Dolowitz \& Marsh, 2000). To succeed, the idea requires changes in context, rules of logic and formulation of the idea. In 2014, a new Law on Higher Education (Parliament of Ukraine, 2014) was adopted which preserves the status of research university but the same year the resolution with criteria of research university was abolished. This means the development of a new approach to defining the research university, new criteria; in other words, again new rules of context, logic and formulation of this idea. In this way, 'research universities 2.0' in Ukraine may come closer to their destination - drivers of knowledge and innovation for a knowledge-based economy. However, for efficient completion of the translation of the idea of the research university into the Ukrainian context it is also necessary to explore the mismatches in the process of the implementation of the state policy in the universities in order to improve them. This issue requires further exploration.

\section{Acknowledgements}

We would like to thank Ian Dobson for making insightful and constructive comments on this article.

\section{Disclosure statement}

No potential conflict of interest was reported by the authors.

\section{References}

AAU, LERU, G8 and C9. (2013). HEFEI Statement on the ten characteristics of contemporary research universities. Retrieved from http://www.leru.org/files/news/Hefei_statement.pdf

Altbach, P. (2004). The costs and benefits of world-class universities. Academe, 90(1), 20-23. doi:10.2307/40252583 
Altbach, P. (2009). Peripheries and centers: Research universities in developing countries. Asia Pacific Education Review, 10, 15-27. doi:10.1007/s12564-009-9000-9

Altbach, P. (2013). Advancing the national and global knowledge economy: The role of research universities in developing countries. Studies in Higher Education, 38(3), 316-330. doi:10.1080/ 03075079.2013.773222

Beland, D., \& Cox, R. (2010). Ideas and politics. In D. Beland \& R. Cox (Eds.), Ideas and politics in social science research. New York: Oxford University Press.

Borisov, I., \& Zapryagaev, S. (2001). Complexes of universities and education of universities. University Management, 3(18). Retrieved from http://ecsocman.hse.ru/text/17981961/

Brunsson, N. (1989). The organisation of hypocrisy: Talk, decision and action in organisation. Chichester: John Wiley.

Bunina, L. (2013). The history of higher education in Ukraine. Naukovuy Visnuk Donbasu, 3. Retrieved from http://nbuv.gov.ua/UJRN/nvd_2013_3_2

But'ko, M. (2013). General guidelines of higher pedagogical education transformation in Belarus, Russia and Ukraine in post-soviet period. Gileya: Research Bulletin, 72, 730-735.

Cabinet of Ministers of Ukraine. (2007a). State targeted scientific-technical and social program 'science in universities' for 2008-2012. Retrieved from http://www.kmu.gov.ua/control/uk/ cardnpd?docid $=92768743$

Cabinet of Ministers of Ukraine. (2007b). On approval of statute of National Technical University of Ukraine 'Kyiv Polytechnic Institute'. Retrieved from http://studprofkom.kpi.ua/statut

Cabinet of Ministers of Ukraine. (2007c). On approval of the concept of the state targeted program 'science in universities' for 2008-2012. Retrieved from http://zakon4.rada.gov.ua/laws/show/ $548-2007-\%$ D1\%80

Cabinet of Ministers of Ukraine. (2009a). Issues of National University Lviv Polytechnic. Retrieved from http://zakon1.rada.gov.ua/laws/show/713-2009-\%D0\%BF

Cabinet of Ministers of Ukraine. (2009b). Issues of Ivan Franko National University of Lviv. Retrieved from http://zakon1.rada.gov.ua/laws/show/797-2009-\%D0\%BF

Cabinet of Ministers of Ukraine. (2009c). Issues of National University Ostroh Academy. Retrieved from http://zakon1.rada.gov.ua/laws/show/798-2009-\%D0\%BF

Cabinet of Ministers of Ukraine. (2009d). Issues of National University 'Kyiv-Mohyla Academy'. Retrieved from http://zakon1.rada.gov.ua/laws/show/799-2009-\%D0\%BF

Cabinet of Ministers of Ukraine. (2009e). Issues of National Mining University. Retrieved from http://zakon1.rada.gov.ua/laws/show/1013-2009-\%D0\%BF

Cabinet of Ministers of Ukraine. (2010a). Some issues of awarding a status of self-governed (autonomous) research national university to higher education institutions. Retrieved from http://zakon1.rada.gov.ua/laws/show/76-2010-п

Cabinet of Ministers of Ukraine. (2010b). On approval of the regulations on research university. Retrieved from http://zakon4.rada.gov.ua/laws/show/163-2010-\%D0\%BF

Cabinet of Ministers of Ukraine. (2010c) On making changes to the resolution of the Cabinet of Ministers from $17^{\text {th }}$ February 2010 №163. Retrieved from http://zakon1.rada.gov.ua/laws/show/ 786-2010-\%D0\%BF

Commission of the European Communities (COM). (1997). Towards a Europe of knowledge. Brussels. Retrieved from http://eur-lex.europa.eu/legal-content/EN/TXT/?uri=URISERV\%3Ac11040

Commission of the European Communities (COM). (2003). The role of universities in the Europe of knowledge. Brussels. Retrieved from http://eur-lex.europa.eu/legal-content/EN/TXT/PDF/? uri=CELEX:52003DC0058\&from $=$ EN

Czarniawska, B., \& Joerges, B. (1996). Travels of ideas. In B. Czarniawska \& G. Sevón (Eds.), Translating organisational change (pp. 13-48). Berlin: Walter de Gruyter.

Czarniawska, B., \& Sevón, G. (Eds.). (1996). Translating organizational change. Berlin: Walter de Gruyter.

Degn, L. (2014). Making sense of university ideas. Exploring how ideas influence management practice and perceptions in Danish universities (Doctoral dissertation). Aarhus University, Denmark. Retrieved from http://politica.dk/forlaget/politicas-phd-serie/lise-degn/ 
Dolowitz, D., \& Marsh, D. (2000). Learning from abroad: The role of policy transfer in contemporary policy-making governance. An International Journal of Policy and Administration, 13(1), 5-24.

Gordon, R. (1975). Interviewing: Strategy, techniques and tactics. Homewood, IL: Dorsey Press.

Kearney, M.-L., \& Lincoln, D. (2013). Research universities: Networking the knowledge economy. Editorial. Studies in Higher Education, 38(3), 313-315. doi:10.1080/03075079.2013.778682

Kovalchuk, T. (2010). Funding of innovations and budget policy in context of current economic reforms. Financial Ukraine. Retrieved from http://www.ufin.com.ua/analit_mat/gkr/146.htm

Lenger, A. (2008). Big-bang versus gradualism? Towards a framework for understanding institutional change in Central and Eastern Europe. Conference paper. Retrieved from https:// www.wipo.uni-freiburg.de/dateien/tagungen/reformen/alexander_lenger_big-bang_versus_ gradualism.pdf

Maximova-Mentzoni, T. (2013). The changing Russian university: From state to market. Oxon: Routledge.

Mohrman, K., Ma, W., \& Baker, D. (2008). The research university in transition: The emerging global model. Higher Education Policy, 21(1), 5-27. doi:10.1057/palgrave.hep.8300175

Morris, T., \& Lancaster, Z. (2006). Translating management ideas. Organisation Studies, 27, 207233. doi:10.1177/0170840605057667

Oleksiyenko, A. (2014). Socio-economic forces and the rise of the world-class research university in the post-Soviet higher education space: The case of Ukraine. European Journal of Higher Education, 4(3), 249-265. doi:10.1080/21568235.2014.916537

Parliament of the Republic of Estonia (Riigikogu). (1992). Republic of Estonia education act. Retrieved from https://www.riigiteataja.ee/en/eli/524042014002/consolide

Parliament of the Republic of Latvia. (1995). Law on higher education establishments. Retrieved from http://www.aic.lv/rec/Eng/leg_en/LV_lik/HE_law_en.htm

Parliament of the Republic of Lithuania. (2009). Republic of Lithuania law on higher education and research. Retrieved from https://www.mruni.eu/mru_lt_dokumentai/direkcijos/studiju_direkcija/ teises_aktai/Lietuvos\%20teises\%20aktai/Law_on_Higher_Education_and_Research.pdf

Parliament of Ukraine. (1991a). Law on entrepreneurship. Retrieved from http://zakon4.rada.gov. ua/laws/show/698-12

Parliament of Ukraine. (1991b). Law on education. Retrieved from http://zakon3.rada.gov.ua/ laws/show/1060-12/page

Parliament of Ukraine. (2002). Law on higher education. Retrieved from http://zakon4.rada.gov. ua/laws/show/2984-14

Parliament of Ukraine. (2014). Law on higher education. Retrieved from http://zakon3.rada.gov. ua/laws/show/1556-18

President of Ukraine. (1995). Regulations on the National Institution of Ukraine. Retrieved from http://zakon3.rada.gov.us/laws/show/451/95

President of Ukraine. (1996). On some issues of awarding the higher education institutions the status of national. Retrieved from http://zakon4.rada.gov.ua/laws/show/304/96

President of Ukraine. (2008). On raising the status of Taras Shevchenko National University of Kyiv. Retrieved from http://zakon3.rada.gov.ua/laws/show/412/2008

Rogers, E. (1983). Diffusion of Innovations. New York, NY: Free Press.

Sahlin, K., \& Wedlin, L. (2008). Circulating ideas: Imitation, translation and editing. In R. Greenwood, Ch. Oliver, R. Suddaby, \& K. Sahlin-Andersson (Eds.), The Sage handbook of organizational institutionalism (pp. 218-241). Thousand Oaks, CA: Sage.

Sahlin-Andersson, K. (1996). Imitating by editing success: The construction of organizational fields. In B. Czarniawska \& G. Sevon (Eds.), Translating organizational change (pp. 69-92). Berlin, NY: Walter de Gruyter.

Sahlin-Andersson, K., \& Engwall, L. (2002). The expansion of management knowledge. Carriers, flows and sources. Standford, CA: Standford University Press.

Salmi, J. (2009). The challenge of establishing world-class universities. Washington, DC: World Bank. 
Stadnyi, Y. (2013). The status of the national higher education institutions: Political dimension. Retrieved from http://ru.osvita.ua/vnz/33733/

State Statistics Service of Ukraine. (2015). Higher education institutions. Retrieved from http:// www.ukrstat.gov.ua

Ukrainian Independent Information Agency of News (UNIAN). (2009). The Cabinet of Ministers supported the development of the network of research universities. Retireved from http://www. unian.ua/society/268867-kabmin-pidtrimav-rozvitok-mereji-doslidnitskih-universitetiv.html

World Bank. (2008). Knowledge Economy Index (KEI) 2008 rankings. Retrieved from http:// siteresources.worldbank.org/INTUNIKAM/Resources/KEI2008Highlights_final12052008.pdf

World Bank. (2012). Knowledge Economy Index (KEI) 2012 rankings. Retrieved from http:// siteresources.worldbank.org/INTUNIKAM/Resources/2012.pdf

Zgurovskyi, M. (2005). Ukraine still has chance. Retrieved from http://gazeta.dt.ua/ EDUCATION/ukrayina_sche_mae_shans.html

Zgurovskyi, M. (2006). Research universities: Chance for Europe. Retrieved from http://gazeta.dt. ua/EDUCATION/doslidnitski_universiteti_shans_dlya_evropi.html 